Економічні науки: збірник наукових праџь Луцького національного технічного університету. - Серія "Регіональна економіка". - Випуск 15 (59). - Редкол.: відп. ред. д.е.н., професор Л.Л. Ковальська. - Луцьк: ІВВ Луцького НТУ, 2018. - 292 с.

УДК 332.12:316.323

Джаман М.O.

доктор економічних наук, професор ІПК ДСЗ України, академік АЕН України

\title{
ВПЛИВ ТУРИСТИЧНОГО ОБРАЗУ РЕГІОНУ НА ІНВЕСТИЦІЙНУ ПРИВАБЛИВІСТЬ ТА ЕКОНОМІЧНИЙ РОЗВИТОК ТЕРИТОРІї
}

Стаття присвячена дослідженню туристичного образу регіону як фактора інвестиційної привабливості та економічного розвитку території. У статті зроблено аналіз наукових праць західних, російських і вітчизняних вчених-науковців. Виявлено, що досить часто зустрічається аналіз феномена імідж регіону в політичній, економічній, географічній соціальній, маркетинговій площині тощо, але безпосередньо проблема туристичного образу регіону належного висвітлення не отримала. Визначена категорія регіону в нашому розумінні і конкретизовані принципи, якими доцільно керуватися для створення культурно-образної характеристики території. Представлено як туристичний образ регіону сприяє тому, щоб ту чи іншу територію поважали не тільки споживачі туристичного продукту, а й бізнесмени і інвестори та прагнули відвідати, працювати і навіть жити на ній; як туристичний образ регіону позитивно впливає на рівень свідомості суспільства, на його естетичне і екологічне виховання та яким чином він впливає на інвестиційну привабливість та економічний розвиток території.

Ключові слова: образ, імідж, бренд, регіон, конкурентоспроможність регіону, інвестиційна привабливість регіону.

\section{Dzhaman M.}

\section{TOURIST IMAGE OF THE REGION AS A FACTOR OF COMPETITIVENESS AND INVESTMENT ATTRACTIVENESS OF THE TERRITORY}

The article is devoted to the study of the touristic image of the region as a factor of investment attractiveness and economic development of the territory. The article deals with the analysis of scientific works of Western, Russian and Ukrainian scholars. It has been revealed that the scientific works usually contain analysis of the phenomenon of the image of the region in the political, economic, geographical, social and marketing sphere and the TIR problem itself has not been illuminated properly. The category of the region is defined in our understanding and the principles which it is advisable to take into account for the creation of a 
Економічні науки: збірник наукових праџь Луцького національного технічного університету. - Серія "Регіональна економіка". - Випуск 15 (59). - Редкол.: відп. ред. д.е.н., професор Л.Л. Ковальська. - Луцьк: ІВВ Луцького НТУ, 2018. - 292 с.

culturalimage characteristic of the territory are specified. It is shown how the tourist identity of the region contributes to the fact that one or another territory is respected not only by the consumers of the tourist product, but also by businessmen and investors who seek to visit, work and even live on it; as TIR positively affects the level of consciousness of society as well as the level of its aesthetic and environmentaleducation.

Key words: identity, image, brand, region, competitiveness of the region, investment attractiveness of the region.

\section{Джаман М.A. \\ ВЛИЯНИЕ ТУРИСТИЧЕСКОГО ОБРАЗА РЕГИОНА НА ИНВЕСТИЦИОННУЮ ПРИВЛЕКАТЕЛЬНОСТЬ И ЭКОНОМИЧЕСКОЕ РАЗВИТИЕ ТЕРРИТОРИИ}

Статья посвящена туристическому образу региона как фактору формирования конкурентоспособности и инвестиционной привлекательности территории. В статье сделан анализ научных трудов западных, российских и отечественных ученых, выявлено, что очень часто встречается анализ феномена имидж региона в политической, экономической, географической, социальной и маркетинговой плоскости, но непосредственно проблема туристического образа региона необходимого освещения до сих пор не получила. Определена категория региона в нашем понимании и конкретизированы принципы, которыми целесообразно руководствоваться для создания культурно-образной характеристики территории. Представлено как туристический образ региона благоприятствует тому, чтобы ту или иную территорию уважали не только потребители туристического продукта, но и бизнесмены и инвесторы, желающие посетить ее, работать и даже жить на ней; как туристический образ региона положительно влияет на уровень сознания общества, на его эстетическое и экологическое воспитание, а также каким образом он влияет на инвестиционную привлекательность и экономическое развитие территории.

Ключевые слова: образ, имидж, бренд, регион, конкурентоспособность региона, инвестиционная привлекательность региона.

Постановка проблеми. Існуючі розбіжності у господарському, суспільному і політичному розвитку регіонів України зумовлені не тільки особливостями їх розташування, а здебільшого неефективним використанням власних ресурсів. Виправити таку ситуацію можуть тільки ті ресурси, які відрізняють його від інших територій. Для цього їх необхідно втілити у конкретних продуктах, що розраховані на певні 
Економічні науки: збірник наукових праиь Луиького національного технічного університету. - Серія "Регіональна економіка". - Випуск 15 (59). - Редкол.: відп. ред. д.е.н., професор Л.Л. Ковальська. - Луцьк: ІВВ Луцького НТУ, 2018. - 292 с.

цільові групи споживача. Однією з таких найперспективніших груп для будь-якого регіону в наш час $є$ туристи, тому актуальною проблемою сьогодення постає створення привабливого туристичного образу регіону, оскільки він здатний позитивно вплинути на його інвестиційну привабливість, темпи економічного розвитку та конкурентоспроможність.

Аналіз останніх досліджень. Підтвердженням актуальності формування образу або іміджу регіону є поява в останні десятиріччя значної кількості наукових праць в цьому плані. Досить часто зустрічається аналіз феномена іміджу в політичній, економічній, географічній, соціальній, маркетинговій площині тощо. Серед західних науковців значний доробок у цьому сенсі становлять праці Г. Берсона, Ф. Котлера, Дж. Траута. Особливого розвитку концепція іміджу держав і території отримала у 90-тих роках минулого століття у працях Ф. Котлера. Серед російських вчених варто назвати праці Е.А. Галумова, А.С. Кирюніна, А.П. Панкрухіна, І.Я. Рожкова, В.Г. Кісмережкіна та ін.

Різні аспекти формування іміджу, у т.ч. України, розглядалися i вітчизняними дослідниками. Це праці А. Акайомової, Д. Богуша, Л.В. Губерського, В. Данилова, Л. Дядечко, Н.О. Качинської, В.Г. Королько, О. Любіцевої, М. Мальської, О. Петкової, Г.М. Сащука, В.I. Терещук, Л.В. Харченко та ін. 3 точки зору формування туристичного іміджу безпосередньо території значний інтерес становлять праці вітчизняного дослідника М.Г.Бойко. Однак попри значну увагу науковців до проблеми формування політичного іміджу держави, проблема формування туристичного образу регіону належного висвітлення ще не отримала.

Постановка завдання. У даній статті ми розглядаємо туристичний образ регіону в якості важливого фактора інвестиційної привабливості та формування його конкурентоспроможності. В даному випадку регіон ми розуміємо як певну територіальну соціально-економічну систему (ТСЕС), що характеризується цілісністю і 
Економічні науки: збірник наукових праиь Луиького національного технічного університету. - Серія "Регіональна економіка". - Випуск 15 (59). - Редкол.: відп. ред. д.е.н., професор Л.Л. Ковальська. - Луцьк: ІВВ Луиького НТУ, 2018. - 292 с.

взаємопов'язаністю іiі складових елементів, а туризм - як «локомотив» лобіювання соціокультурних, інвестиційних та інших інтересів території, як практику актуалізації (товаризації) унікального ціннісного поєднання регіональної культури, національного надбання i формування на цій основі ексклюзивної регіональної економіки.

Завдання, які автор намагається вирішити у даному дослідженні:

- оцінка існуючих поглядів на туристичний образ регіону;

- визначення категорій «регіон» і «туризм»;

- визначення пріоритетності факторів впливу на формування туристичного образу регіону, на його інвестиційну привабливість та конкурентоздатність;

- конкретизацію принципів, якими необхідно керуватися при створенні культурно-образної характеристики регіону;

- оцінка впливу туристичного образу регіону на суспільну свідомість.

Методологія. Під час проведення дослідження було використано методи аналізу та синтезу при вивченні складових ТСЕС; системний підхід, метод узагальнень та логічний під час розгляду визначень категорій «образ», «імідж», «бренд» для надання відповідних висновків та рекомендацій на основі проведеного дослідження.

Виклад основного матеріалу. Загально відомо, що туризм - це єдина виробнича галузь, про яку майже всі згадують iз задоволенням, адже саме слово «туризм» асоціюється у людини 3 приємним місцем, де вдалося побувати в минулому i яке хочеться відвідати в майбутньому. Для України розвиток туризму особливо актуальний, оскільки завдяки йому можна поліпшити соціально-економічну ситуацію в країні. Практикою доведено, що сфера туризму підтримує майже 50 суміжних галузей і створює додаткові робочі місця. Один турист дає роботу 10 особам, а створення одного робочого місця в туризмі у 20 разів дешевше, ніж у промисловості. Такі країни як Італія, Іспанія, Франція, Греція, Кіпр, Польща завдяки розвитку 
Економічні науки: збірник наукових праиь Луиького національного технічного університету. - Серія "Регіональна економіка". - Випуск 15 (59). - Редкол.: відп. ред. д.е.н., професор Л.Л. Ковальська. - Луиьк: ІВВ Луиького НТУ, 2018. - 292 с.

туризму зуміли за досить короткий час подолати економічну кризу. Наприклад, Іспанія і Італія, приймаючи щорічно понад 50 млн. зарубіжних гостей, отримують відповідно 47,9 та 35,4 млрд. доларів прибутку, Австрія, населення якої становить 8,6 млн. жителів, щорічно приймає 18,2 млн. мандрівників, а надходження до бюджету перевищують 15,5 млрд. доларів в рік.

Україна, незважаючи на складну соціально-економічну ситуацію, має всі передумови для розвитку туризму. Вона розташована у центрі Свропи, на перехресті транспортних шляхів, має сприятливі природно-кліматичні умови, багатий рослинний i тваринний світ, цілющі мінеральні джерела (Карпати, Крим, Чорноморське і Азовське узбережжя, басейни Дніпра, Десни, Дунаю, Дністра, Західного Бугу), багату історико-культурну спадщину, людські та матеріальні ресурси. В Україні налічується понад 125 тис. пам'яток археології та архітектури, сотні музеїв. У географічному центрі Європи перехрещуються майже всі європейські культури. 3 давніх часів українська культура $є$ прямою спадкоємницею культури Київської Русі, а іiі своєрідність полягає в тому, що Україна є не лише торговим, але й духовним перехрестям Заходу і Сходу. Перехрестя шляхів веде до Туреччини, Близького Сходу, Індії, Скандинавії та країн Західної Європи.

Туризм має свою специфіку, оскільки тут здійснюється торгівля як послугами, так і товарами. За оцінками фахівців, частка послуг у туризмі становить $75 \%$, товарів - 25\%. Турист користується комплексом послуг, які надають йому в певному місці - регіоні і коли турист вибирає мету своєї подорожі, він завжди порівнює між собою різні місця і ті послуги, які там $\epsilon$, він вибирає із них саме ті, що йому більше всього підходять. Територія, де пропонується комплекс послуг, не обов'язково повинна мати чіткі адміністративні границі. Це може бути i частина регіону, і туристичний центр, і готель, де є всі необхідні для організації відпочинку i розміщення туристів споруди. Такою територією може бути частина області чи держави, або навіть група країн, які турист вибирає за мету своєї мандрівки. 
Економічні науки: збірник наукових праџь Луцького національного технічного університету. - Серія "Регіональна економіка". - Випуск 15 (59). - Редкол.: відп. ред. д.е.н., професор Л.Л. Ковальська. - Луцьк: ІВВ Луцького НТУ, 2018. - 292 с.

Всесвітня туристична організація визначає туристичний регіон як територію, яка володіє великою мережею спеціальних споруд і послуг, що необхідні для організації відпочинку, навчального процесу чи оздоровлення, які продаються туристу, або групі туристів, виробником послуг. Отже, муристичний регіон - це $i$ мета подорожі, $i$ туристичний продукт, $i$ конкурентоздатний суб'єкт, який повинен управлятися як стратегічна комерційна одиниця.

На наш погляд, туристичний регіон можна навіть розглядати з урахуванням вимог тих, які вирушають у подорож. У такому випадку виділяють чотири параметри, виходячи з яких турист, який прибув одного разу на місце відпочинку, хоче задовольнити свої туристичні інтереси ще раз. В залежності від досвіду, мотивації поїздки і відстані від місця проживання відпочиваюча людина виділяє наступні параметри: 1) житло, 2) місце, 3) ландшафт і 4) екскурсії. А якість регіону, як виробника турпослуг, повинна оцінюватись через те, наскільки швидко регіон може пристосувати свої послуги до потреб i вимог замовників. На випадок, якщо якомусь регіону пощастить установити на ринку оптимальні ціни на свої турпродукти i послуги, цей регіон зможе накопичити достатньо засобів, щоб добре оплатити роботу всіх учасників виробничого процесу, а також відмежуватися від зовнішніх ефектів виробництва i споживання турпослуг всіх осіб, що заняті в даному процесі. Таким чином, здатність отримати від ринку достатню кількість накопичення цінностей можна визначити як конкурентоздатність регіону. У зв'язку з цим ми вважаємо, що стратегічна мета туристичного регіону як конкурентної одиниці - це забезпечення інвестиційної привабливості та конкурентоздатності на довгий період. Справа в тому, що взаємодія готелів, підприємств транспорту, торгівлі, їх ринків, населення i стан довкілля активно впливає на конкурентоздатність регіону. Безпосередньо ринки висувають високі вимоги до продукції і, таким чином, стимулюють роботу галузей, і навпаки, - конкурентоздатні галузі зацікавлені у зберіганні і збільшенні кількості вимогливих клієнтів на місцях. 
Економічні науки: збірник наукових праиь Луиького національного технічного університету. - Серія "Регіональна економіка". - Випуск 15 (59). - Редкол.: відп. ред. д.е.н., професор Л.Л. Ковальська. - Луиьк: ІВВ Луиького НТУ, 2018. - 292 с.

Галузі, які отримують від туризму добрий прибуток, одночасно формують у місцевого населення позитивне враження про нього. Це, в свою чергу, створює гарантію їх хлібосольності до туристів і відпочиваючих, що значно полегшує реалізацію інвестицій в інноваційні туристичні проекти. Така обстановка загалом сприяє конкурентоздатності туристичного регіону. Отже, туристичний регіон як конкурентна одиниця включає: а) територіальну суспільно-економічну систему, б) туристичну політику, в) політику охорони навколишнього середовища, г) інтереси економіки, держави i населення, д) раціональне збереження і ефективне використання ресурсів та е) охорону екологічної системи. В умовах інтенсивного розвитку інформаційних технологій різні регіони i локальні території вдаються до активних дій, спрямованих на формування позитивного ставлення до них, що розглядається як механізм залучення нових ресурсів і розширення сфери свого впливу. Серед найважливіших конкурентних переваг регіонального розвитку туристичний образ регіону виступає певним територіальним ресурсом, здатним впливати на перспективу його розвитку i, особливо, на інвестиційну привабливість.

Нині проблеми створення образу, іміджу або бренда території визнаються найважливішими не тільки вченимидослідниками, а й урядовцями. При всій подібності цих понять їх часто використовують як синоніми, але вони мають певні методологічні відмінності. Доволі поширене поняття «образ» включає в себе, на наш погляд, багато інших, таких як «імідж», «стереотип», «міф» тощо. Найбільш широко «образ території» можна визначити як сукупність іiі характеристик, що відображені у свідомості людей. У межах напрацювань цього напряму, образ передбачає відбиття перед усім культурних, історичних, естетичних та інших «ідеальних» значень території. «Імідж регіону» утворюється у суспільній свідомості на основі його реального образу, неодноразово підкресленого відповідними інформаційно-комунікативними технологіями та ідеологічними побудовами. В той же час «бренд території» 
Економічні науки: збірник наукових праџь Луцького національного технічного університету. - Серія "Регіональна економіка". - Випуск 15 (59). - Редкол.: відп. ред. д.е.н., професор Л.Л. Ковальська. - Луцьк: ІВВ Луичького НТУ, 2018. - 292 с.

представляє собою відомий i зафіксований у суспільній свідомості самоцінний імідж. Між тим, туристичний образ дозволяє багатьом країнам, незалежно від рівня їхнього соціально-економічного розвитку, «перекрити» свої негативні явища саме туристичною привабливістю. Ми маємо на думці використати туристичний образ не для приховування проблем регіону, а для того, щоб він став джерелом формування привабливості, зацікавленості суспільного життя в регіоні. Тому пропонуємо проаналізувати сутність та методологічні відмінності понять «образ» - «імідж» - «бренд» території з точки зору застосування їх у туристичній сфері як фактор 3 метою запровадження програм інвестиційної привабливості та конкурентоздатного регіонального розвитку.

Зауважимо, що нині серед вчених найбільш поширено тлумачення «імідж» через поняття «образ». Останній став предметом наукового інтересу цілої низки дисциплін і напрямів: психології, журналістики, лінгвістики, літературознавства, краєзнавства, філософії та ін. Особливо схожий за генезою феномен - образ території - уже довший час виступає предметом уваги географів, культурологів, істориків i археологів. Для підтвердження, у географії територія виступає одним з гносеологічних пріоритетів, тобто створення іiі образу не $\epsilon$ чимось принципово новим. Звертаючись ще до радянських часів, зокрема до спадщини відомого географа В.П. СеменоваТян-Шанського, можна зазначити, що він неодноразово наголошував на необхідності застосування у країнознавчих описах яскравих образних характеристик. У середині 1990-х рр. проблема формування образу країни активно обговорювалася на сторінках наукових журналів, внаслідок чого сформувалася концепція «культурно-образного країнознавства» (М. Мироненко і Д. Замятін). Зокрема М. Мироненко відзначає, що образ - це не стільки термін, скільки символ, знак загальної дослідницької установки, вихідної інтуїції, протилежний за значеннями таким символам, як «схема», «формула», «система» i т.п. За його словами образ - це категорія конкретного мислення, особливу роль у якому відіграють емоційні моменти і 
Економічні науки: збірник наукових праиь Луиького національного технічного університету. - Серія "Регіональна економіка". - Випуск 15 (59). - Редкол.: відп. ред. д.е.н., професор Л.Л. Ковальська. - Луцьк: ІВВ Луцького НТУ, 2018. - 292 с.

особисте ставлення дослідника до предмета. Він припускає наявність особливого, індивідуального і конструюється саме 3 цих сторін реальності [1, с. 56]. Окрему увагу привертають дослідження Д. Замятіна в галузі гуманітарної географії. Лейтмотивом його наукових розвідок є образи територій, які, на його переконання, $є$ місцем, що не прив'язане до окремих географічних координат, а виступає «радше як власний образ або їхня сукупність» [2, с. 32]. Отже, виявлення туристичного образу регіону або країни, дозволяє розділяти його туристичні умови i ресурси, виокремлювати серед інших територій, розкрити неповторний колорит регіонального і національного туристичного простору.

Для створення культурно-образної характеристики території Н.Ю. Замятіна пропонує керуватися наступними принципами:

1) «квантова» організація тексту (тобто інформація має групуватися у певні згустки, тематичні блоки. Важливо щоб вона була просякнута найхарактернішими рисами, які вступають у певну взаємодію і серед них повинна виокремитися провідна, центральна характеристика певної країни);

2) обмежена кількість провідних тем (це означає, що тем має бути не більше семи для однієї країни чи регіону, щоб не ускладнювати і не перевантажувати засвоєння інформаціі);

3) символи тем (кожен «квант» інформації повинен мати свій яскравий символ, доповнений і розширений додатковою інформацією у вигляді тематичного блоку, адже людина, зазвичай, екскурсію або подорож пов'язує в пам'яті із певним предметом, подією чи коротким яскравим спогадом);

4) нарощування теми (тема має повторюватися кілька разів, лаконічно і в різних варіантах. Візуальні ознаки повинні підкріплювати тему у формі «портрета» чи фотографії конкретного місця, а аналітичні коментарі повинні бути 3 причинно-наслідковими зв'язками);

5) географічне представлення образу (окрім звукових, смакових, візуальних та інших асоціацій корисно подати географічну низку - адже розподіл регіональних відмінностей 
Економічні науки: збірник наукових праиь Луиького національного технічного університету. - Серія "Регіональна економіка". - Випуск 15 (59). - Редкол.: відп. ред. д.е.н., професор Л.Л. Ковальська. - Луцьк: ІВВ Луцького НТУ, 2018. - 292 с.

«культурного ландшафту» допомагає розглядати регіон не тільки як соціальне середовище, але і як інформаційний простір, управління яким відкриває можливості отримати реальні конкурентні переваги);

6) перевірка контексту сприйняття (враховуючи, що будь-який текст сприймається кожним по-різному, то образне відтворення дійсності і образний підхід продукує неабияку суб'єктивність у створенні країнознавчих текстів) [3, с. 4-6].

Ми цілком підтримуємо наведені принципи i думку Д.М. Замятіна в тому, що об'єктивність образу будь-якого регіону залежить від: а) врахування усіх динамічних властивостей об' єктивно-образної реальності, що і визначає інформаційну місткість образу, б) географічного простору в образі країни, який стає максимально структурованим i усвідомленим у межах конкретної історичної епохи; в) розподілу «ідеальних значень» і «сеансів», що стають у центрі будь-якої характеристики і $€$ основою для створення туристичного образу території; г) туристичного образу, який може продукувати не тільки художньо-образне відтворення дійсності, а й певне перетворення регіону [2, с.114-116]. Тобто туристичний образ регіону мимоволі, підсвідомо спирається на реальні ресурси регіону чи країни, акцентує здебільшого позитивні характеристики і нівелює невигідні. Це тому, що сама специфіка туризму продукує певне «зачарування» територією, ідеалізує іi, а «за кадром» залишає певні недоліки. Усе це наводить на думку, що у більшості випадків ми маємо справу саме зі спеціально сконструйованим туристичним образом, який більш доречно назвати «іміджем». Його можна розглядати як особливий вид реальності, своєрідний територіальний ресурс, що здатний відповідно впливати на розвиток територіальної соціально-економічної системи (ТСЕС) регіону, якісно змінюючи простір.

Актуальним є i те, що нині існує велика кількість напрацювань, присвячених іміджу особистості, товарів і послуг, партій, підприємств і корпорацій тощо. Імідж території також неодноразово привертав увагу дослідників, передусім у площині 
Економічні науки: збірник наукових праиь Луиького національного технічного університету. - Серія "Регіональна економіка". - Випуск 15 (59). - Редкол.: відп. ред. д.е.н., професор Л.Л. Ковальська. - Луцьк: ІВВ Луичького НТУ, 2018. - 292 с.

формування іміджу держави. 3 цього приводу А.Ю. Парфіненко, проаналізувавши існуючі визначення іміджу регіону стверджує, що «імідж - це процес комунікативний, покликаний скорегувати уявлення і запити певних цільових груп» [4, с. 21-22]. Відомий український дослідник П. Бєлєнький імідж регіону відносить до числа «дієвих механізмів забезпечення його конкурентних переваг.., є тим ресурсом, що дає змогу вирізняти на тлі інших регіонів, забезпечуючи приплив грошових ресурсів у вигляді інвестиційних, туристичних та міграційних потоків, впливаючи на продуктивність ведення господарства, тобто підвищує конкурентоздатність регіону» [5, с. 16]. Здатність іміджу виступати в сучасних умовах важливим конкурентним ресурсом відзначають й інші науковці (І.С. Важеніна, Л.М. Хижняк). Таким чином, створення позитивного іміджу регіону чи країни розглядається сьогодні як одне з найбільш пріоритетних завдань державної політики і національної безпеки.

Позитивний імідж сприяє тому, щоб ту чи іншу територію поважали не тільки споживачі туристичного продукту, але й іноземні бізнесмени та інвестори, прагнули їі відвідати і навіть на ній працювати, комфортно і престижно мешкати в іiі межах, щоб туди 3 великим нетерпінням хотіли приїздити туристи. Як підтвердження сказаному, М. Бойко підкреслює, що в умовах глобалізації туристична привабливість значною мірою залежить від «використання важелів геодиференціації та позиціонування туристичного простору для відображення відмітних особливостей пропозиції національного туристичного продукту» [6, с. 305]. Отже, у нинішніх умовах господарювання туристична привабливість території залежить не тільки від іï туристично-рекреаційних ресурсів, а й від конкретних комунікативних стратегій, що застосовуються 3 метою інформування туристів про особливості і переваги даної місцевості.

В умовах глобалізації туристичний імідж регіону відчутно набуває статусу одного з основних ресурсів, що визначає його економічну, політичну i соціокультурну перспективу. Він служить однією 3 визначальних складових національного 
Економічні науки: збірник наукових праиь Луиького національного технічного університету. - Серія "Регіональна економіка". - Випуск 15 (59). - Редкол.: відп. ред. д.е.н., професор Л.Л. Ковальська. - Луцьк: ІВВ Луиького НТУ, 2018. - 292 с.

бренду країни. Не випадково дослідники відзначають, що необхідно відрізняти процес формування іміджу територіального утворення, як позитивного комунікативного поля, і процес «репутаційного бренд-менеджменту», який потрібно розуміти як «постійний процес, націлений на реалізацію таких основних напрямків: формування, підтримка $\mathrm{i}$ захист репутації» [7, с. 52]. Таким чином, територіальний брендінг - це процес формування репутації території i управління нею.

Доцільно зауважити, що значні дослідження методологічних, методичних та технологічних алгоритмів створення, просування i управління брендами територій представлено передусім у працях зарубіжних науковців i практиків: Д. Аакера, К. Асплунда, В. Кісмерешкіна, Ф. Котлера, В. Ляпорова, А. Панкрухіна, I. Рожкова, С. Анхольта, Дж. Сіммонса, Д. Хайдера та ін. Зазначеними проблемами займалися також і вітчизняні вчені: Д. Богуш, М. Бойко, С. Будько, О. Зозульок, С. Ілляшенко, Р. Колядюк, А. Парфіненко, В. Файфура, О. Шевченко та ін. Однак визначними фахівцями у сфері територіального брендінгу вважаються британські експерти Саймон Анхольт і Уоллі Уоллінс. Так, ще у 1990-х роках С. Анхольт придумав і перший використав «national branding» i «place brand», заснував дослідження «National Brands Index». На його думку у глобальному світі кожне місто, регіон, країна повинні «конкурувати (боротися) за туристів, інвестиції, довіру, репутацію і пошану збоку світових ЗМІ. Імідж країни - це іiі конкурентна перевага. Брендінг країни - це стратегічний підхід до розвитку цієї переваги і бачення того, куди країна може рухатися. Без такого бачення країна не зможе конкурувати» [8, с. 50]. Він визначає брендінг країни як систематичний процес узгодження дій, поведінки, інвестицій, інновацій і комунікацій країни для реалізації стратегії конкурентної ідентичності. Сприйняття держав у системі координат брендів логічно приводить до появи рейтингів брендів держав і міст світу, а також до утворення відповідних державних структур, що 
Економічні науки: збірник наукових праиь Луиького національного технічного університету. - Серія "Регіональна економіка". - Випуск 15 (59). - Редкол.: відп. ред. д.е.н., професор Л.Л. Ковальська. - Луцьк: ІВВ Луиького НТУ, 2018. - 292 с.

займаються створенням позитивного іміджу держави. Так, 3 недавнього часу C. Анхольт i американська дослідницька компанія «Global Market Insite» запропонували щорічні оцінки вартості брендів, або репутації країн світу. Репутацію визначають за такими факторами: 1) туристична привабливість, 2) людський капітал, 3) якість експортованих товарів, 4) справедливість уряду, 5) привабливість культури і спорту, 6) інвестиційна привабливість і 7) привабливість країни як місця проживання. Запропоновані фактори можуть служити індикаторами для визначення бренду будь-якої країни чи регіону.

Розглядаючи концептуальні основи репутації території, російська дослідниця І.С. Важеніна відзначає, що бренд формується на основі яскраво підкресленого позитивного іміджу території i $\epsilon$ найвищим проявом емоційних споживацьких запитів. Вона стверджує, що «бренд - це сукупність унікальних якостей, самоцінних людських цінностей, що відображають своєрідність, неповторні оригінальні споживацькі характеристики даної території і спільноти, які $є$ широковідомими, отримали суспільне визнання i мають стабільний попит з боку споживачів даної території» [9, с. 20]. На іiі думку «бренд території» - змістовне, складне і системне поняття, що може бути схарактеризоване як: а) унікальний емоційно-позитивний образ, б) обіцянка споживачам території бажаних споживацьких якостей, в) гарантія якісного задоволення запитів споживача території, г) підвищений суб'єктивний рівень цінності території для споживача та його задоволення, д) найважливіший фактор конкурентних переваг i доходів регіону [9, с. 35]. Тобто, будь-яка територія (регіон, область чи місто) пропонує компаніям і громадянам певний продукт, а саме - себе, як центр туризму, як місце для бізнесу i вкладання інвестицій, як постачальника якісних товарів тощо.

Висновки. Таким чином, розмежування понять «образ», «імідж» і «бренд» території становить не тільки теоретичний інтерес, але має і прикладне значення. Туристичний образ доцільно використовувати як джерело формування 
Економічні науки: збірник наукових праџь Луцького національного технічного університету. - Серія "Регіональна економіка". - Випуск 15 (59). - Редкол.: відп. ред. д.е.н., професор Л.Л. Ковальська. - Луцьк: ІВВ Луиького НТУ, 2018. - 292 с.

привабливості і зацікавленості суспільного життя в регіоні. Внаслідок цього він стає предметом наукового інтересу цілої низки дисциплін i напрямків дослідження. Водночас він акцентує здебільшого позитивні характеристики і нівелює невигідні, а також здатний позитивно впливати на розвиток ТСЕС регіону, змінюючи простір.

Туристична привабливість території у нинішніх умовах господарювання залежить не тільки від ¥іi туристичнорекреаційних ресурсів, а й від конкретних комунікативних стратегій, що застосовуються 3 метою інформування туристів про переваги даної місцевості. Для створення культурнообразної характеристики регіону доцільно керуватися наступними принципами: «квантовою» організацією тексту; обмеженою кількістю провідних тем; символами i нарощуванням тем; географічним представленням образу та перевіркою контексту сприйняття.

Однак перетворення ексклюзивного образу регіону на його позитивний туристичний імідж і бренд території потребує в даний час ще активного вивчення і прикладної реалізації. Адже, звертаючись до універсальної природи людини, апелюючи до ii цінностей і інтересів, образи територій здатні ставати соціально значущими для багатьох, а в перспективі пропагувати свою філософію і відповідно комплексно впливати на суспільство в цілому. В першу чергу на рівень його свідомості, естетичного і екологічного виховання.

1. Мироненко Н.С. Страноведение: теория и методы/ Н.С. Мироненко. - М.: Аспект Пресс, 2001. - 272 с.

2. Замятин Д.Н. Образ страны: структура и динамика /Д.Н. Замятин // Общественные науки и современность. - 2000.- №1. С.107-115.

3. Замятина Н.Ю. Принципы создания образа мест / Н.Ю. Замятина // География и экология в школе ХХІ века. - 2004. № 2. - С. 3-11.

4. Туристичний імідж регіону: монографія / за ред. А.Ю. Парфіненко. Х.: ХНУ ім. В.Н. Каразіна, 2011.- 312 с.

5. Бєлєнький П. Дослідження проблеми конкурентоспроможності / П.Бєлєнький // Вісник НАН України. 2007. № 5. - С. 8 - 18. 
Економічні науки: збірник наукових праць Луиького національного технічного університету. - Серія "Регіональна економіка". - Випуск 15 (59). - Редкол.: відп. ред. д.е.н., професор Л.Л. Ковальська. - Луцьк: ІВВ Луиького НТУ, 2018. - 292 с.

6. Бойко М.Г. Організаційно-економічний механізм формування національного бренду/ М.Г. Бойко // Теоретичні та прикладні питання економіки. - Вип. 21.- С. 304-309.

7. Блинов А. Имидж территориальных образований как один из инструментов привлечения инвестиций / А. Блинов // Волга-Бизнес. - 2002. № 11.- C. 52-53.

8. Анхольт С. Создание бренда страны / С. Анхольт // БрендМенеджмент. - 2007. - № 1. - С. 50-52.

9. Важенина И.С. Концептуальные основы формирования имиджа и репутации территории в конкурентной среде: автореф. дис. на соискание учён. степени д. э. н. / И.С. Важенина. - Екатеринбург, 2008. - 48 с. 